The

\title{
Incretin-based therapies: can we achieve glycemic control and cardioprotection?
}

\section{Franca S Angeli and Richard P Shannon}

Department of Medicine, Perelman School of Medicine, University of Pennsylvania, Hospital of the University of Pennsylvania, 3400 Spruce Street, Centrex 100, Philadelphia, Pennsylvania 19104, USA
Correspondence should be addressed to R P Shannon Email richard.shannon @uphs.upenn.edu

\begin{abstract}
Glucagon-like (GLP-1) is a peptide hormone secreted from the small intestine in response to nutrient ingestion. GLP-1 stimulates insulin secretion in a glucose-dependent manner, inhibits glucagon secretion and gastric emptying, and reduces appetite. Because of the short circulating half-life of the native GLP-1, novel GLP-1 receptor (GLP-1R) agonists and analogs and dipeptidyl peptidase 4 (DPP-4) inhibitors have been developed to facilitate clinical use. Emerging evidence indicates that GLP-1-based therapies are safe and may provide cardiovascular (CV) benefits beyond glycemic control. Preclinical and clinical studies are providing increasing evidence that GLP-1 therapies may positively affect CV function and metabolism by salutary effects on CV risk factors as well as via direct cardioprotective actions. However, the mechanisms whereby the various classes of incretin-based therapies exert CV effects may be mechanistically distinct and may not necessarily lead to similar CV outcomes. In this review, we will discuss the potential mechanisms and current understanding of CV benefits of native GLP-1, GLP-1R agonists and analogs, and of DPP-4 inhibitor therapies as a means to compare their putative $\mathrm{CV}$ benefits.
\end{abstract}

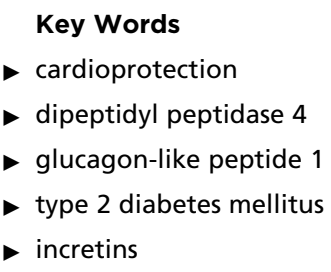

Journal of Endocrinology (2014) 221, T17-T30

\section{Introduction}

Despite significant advances in anti-glycemic therapies, cardiovascular disease (CVD) remains the major cause of morbidity and mortality in patients with type 2 diabetes mellitus (T2DM) (Fox et al. 2004, Booth et al. 2006, Perk et al. 2012). Moreover, certain classes of potent antidiabetic agents reduce microvascular complications but carry a increased risk of cardiovascular (CV) events (Nissen \& Wolski 2007, Tzoulaki et al. 2009). At a time when T2DM constitutes a worldwide epidemic, there is a growing demand for new treatments that not only control plasma glucose but also reduce macrovascular complications.

Glucagon-like peptide 1 (GLP-1) is a peptide hormone synthesized in and secreted by enteroendocrine L cells in the gut and by the brainstem in the CNS. GLP-1 is secreted from the gut at low basal levels in the fasted state, peaking in response to nutrient ingestion, and leading to enhancement of glucose-stimulated insulin secretion, inhibition of glucagon secretion and gastric emptying, and reduction of appetite (Drucker 2006, Ussher \& Drucker 2012). The native peptide (GLP-1 (7-36) amide) is rapidly cleavage by the dipeptidyl peptidase 4 (DPP-4) enzyme (Deacon et al. 1995), limiting circulating half-life and subsequent biological effects on pancreatic $\beta$ cells. This pharmacokinetic response has led to the development of novel GLP-1 receptor (GLP-1R) agonists and analogs that are DPP-4-resistant and thus have a longer half-life. Similarly, DPP-4 inhibitors have also been developed that prolong the half-life of circulating native

Published by Bioscientifica Ltd.

This paper is one of five papers that form part of a thematic review section on

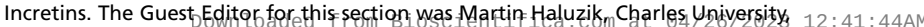

$\begin{aligned} \text { Prague, Czech Republic. via free access } & \end{aligned}$ 
GLP-1 (Fakhoury et al. 2010, Cernea \& Raz 2011). All classes of agents share the same insulinotropic properties and have been shown to have similar glucose-lowering properties (Fineman et al. 2012). However, they vary with respect to extra-pancreatic effects, including weight loss and blood pressure (BP) control. Emerging evidence indicates that GLP-1-based therapies are safe and may provide CV benefits (Monami et al. 2011, Sun et al. 2012), making this class of agents a particularly attractive option for treating T2DM (Addison \& Aguilar 2011).

Interestingly, the $\mathrm{CV}$ benefits of GLP-1 therapies seems to be only partially mediated by their positive action on glucose control in T2DM (Ussher \& Drucker 2012). The mechanisms whereby this class of agents mediates $\mathrm{CV}$ effects may be distinct, not necessarily leading to similar outcomes. This review discusses the potential mechanisms and current understanding of the associated CV benefits of native GLP-1 (Barragan et al. 1994, 1996) and its metabolites, GLP-1R agonists and analogs, and of DPP-4 inhibitor therapies (Table 1).

\section{Improving glucose control: effect on CV outcomes}

GLP-1R activation stimulates adenylate cyclase, which increases CAMP, leading to activation of protein kinase A (PKA) and insulin biosyntheses by the $\beta$ cells (Li et al. 2003).
GLP-1 stimulates insulin release in a $\mathrm{K}_{\mathrm{ATP}}$-mediated, glucose-dependent fashion. GLP-1 also inhibits glucagon secretion from pancreatic $\alpha$ cells, reducing hepatic glucose production, further facilitating improvement in glycemic control. Thus, the metabolic profile of GLP-1-based therapies is broad and not restricted to its role as an insulin secretagogue. Although results of studies examining the association between glycemic control with alternative anti-diabetic agents and CV outcomes in patients with T2DM have been inconsistent (Barragan et al. 1996, Control et al. 2009, Ray et al. 2009), the broader metabolic profile of GLP-1 may lead to beneficial effects on CV outcomes not seen with the other anti-diabetic agents (Ceriello 2006, Ussher \& Drucker 2012, Herzlinger $\&$ Horton 2013). As presented in Table 2, over 90000 patients are currently enrolled in clinical studies designed to assess the CV safety and efficacy of incretin-based therapies and hopefully these will provide a better understanding of the influence of GLP-1 in CVD (Scirica et al. 2011, White et al. 2011, Sivertsen et al. 2012). Most of new trials enrolled thousands of patients and are adequately powered for safety and to show superiority rather than non-inferiority. Recently, preliminary results from the non-inferiority Vildagliptin in Ventricular Dysfunction Diabetes (VIVIDD) trial were presented at the Heart Failure Congress in Lisbon (McMurray 2013). In this study, 254 patients with T2DM and New York Heart

Table 1 GLP-1-based therapies: current knowledge of differences between native GLP-1, GLP-1 analogs and agonists, and DPP-4 inhibitors

\begin{tabular}{|c|c|c|c|}
\hline & $\begin{array}{l}\text { Native } \\
\text { GLP-1 (7-36) }\end{array}$ & $\begin{array}{l}\text { GLP-1 analogs } \\
\text { and agonists }\end{array}$ & DPP-4 inhibitors \\
\hline Administration & Infusion/injection & Injection & Oral \\
\hline GLP-1 level & Pharmacological & Pharmacological & Physiological \\
\hline DPP-4-resistant & No & Yes & NA \\
\hline Mechanism of action & $\begin{array}{l}\text { GLP-1 receptor } \\
\text { and metabolites }\end{array}$ & GLP-1 receptor & $\begin{array}{l}\text { GLP-1 receptor, SDF1 } \alpha, \text { BNP, } \\
\text { decrease cytokines }\end{array}$ \\
\hline \multicolumn{4}{|l|}{ Metabolic actions } \\
\hline FPG & Improved & Improved & Improved \\
\hline PPG & Improved & Improved & Improved \\
\hline HbA1c & Improved & Improved & Improved \\
\hline Glucagon & Reduced & Reduced & Reduced \\
\hline Insulin sensitivity & Enhanced/neutral & Improved & Unknown \\
\hline Lipid profile & Improved & Improved & Improved \\
\hline Weight effects & Loss & Loss & Neutral \\
\hline \multicolumn{4}{|l|}{ Cardiovascular actions } \\
\hline Heart rate ${ }^{a}$ & Unmodified & Unmodified/increased & $?$ \\
\hline Blood pressure ${ }^{a}$ & Reduced & Reduced & Reduced \\
\hline Cardioprotection & Present & Present & Present \\
\hline Cardiac function & Improved & Improved & Improved \\
\hline
\end{tabular}

FPG, fasting plasma glucose; PPG, postprandial plasma glucose; BNP, brain natriuretic peptide; CV, cardiovascular; DPP-4, dipeptidyl peptidase 4; GLP-1, glucagon-like peptide 1; NA, not applicable; SDF1 $\alpha$, stromal cell-derived factor-1 $\alpha$; ?, Uncertain/not known or definite. ${ }^{a}$ Clinical studies.

http://joe.endocrinology-journals.org DOI: 10.1530/JOE-13-0195
๑ 2014 Society for Endocrinology Printed in Great Britain
Published by Bioscientifica Ltd 

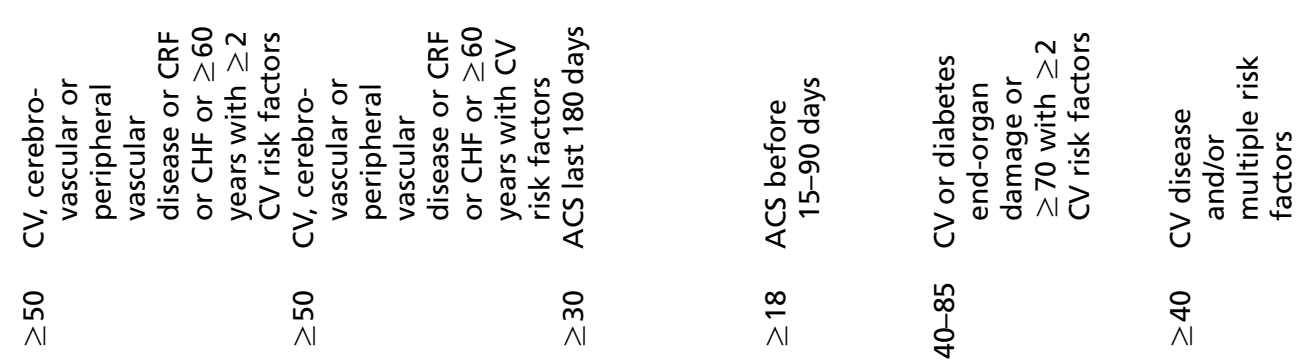

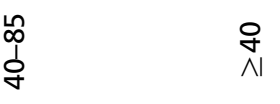

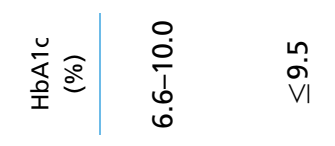

$\stackrel{\circ}{\wedge}$

$\begin{array}{ll}\infty & \infty \\ N & \infty \\ N & 0\end{array}$

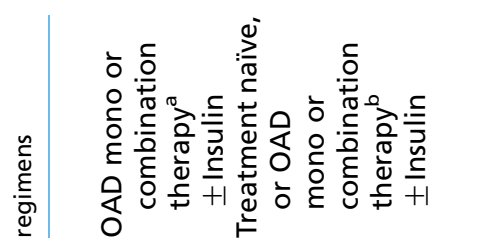

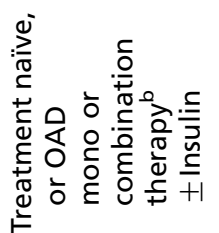

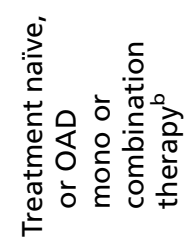

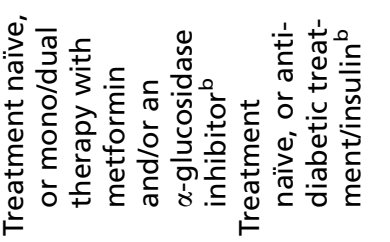

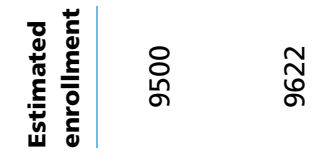

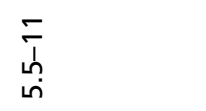

స్丶

$n$
$\infty$
0
$n$
0
0
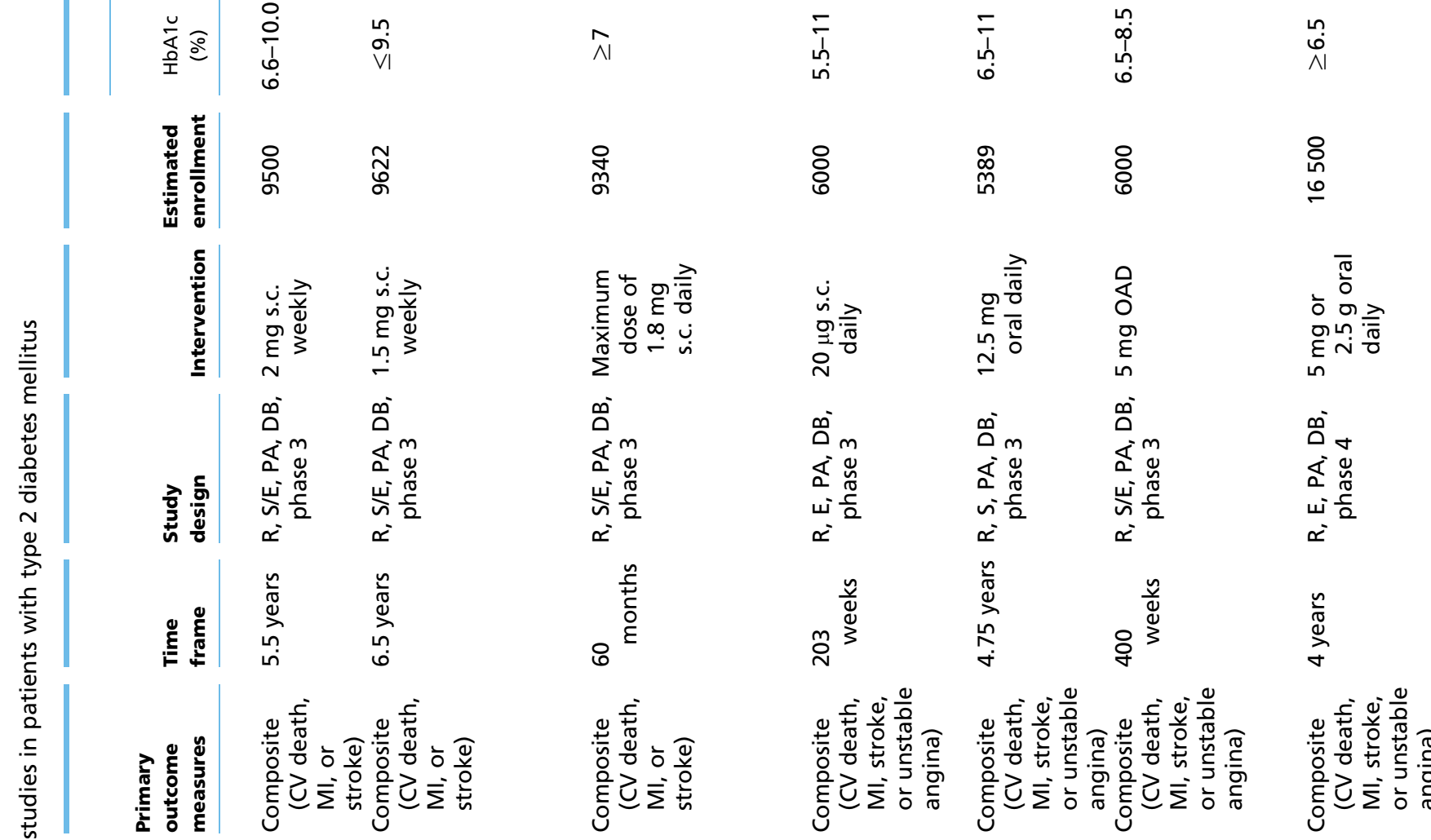

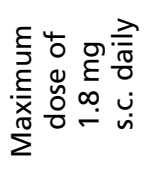

ดั

¿̛̣

岕究

$8^{\stackrel{n}{+}}$

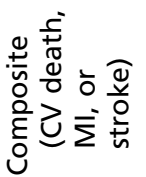

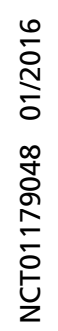

赵
응

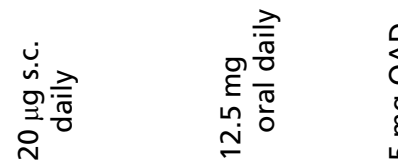

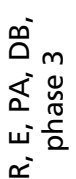

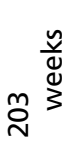

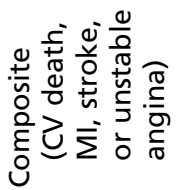

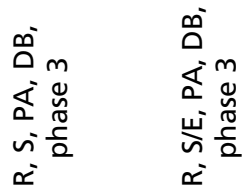

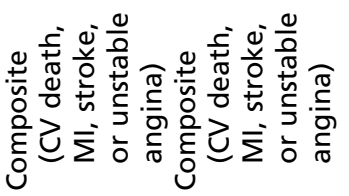

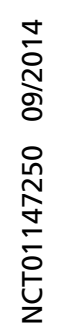

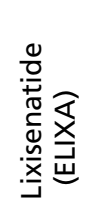

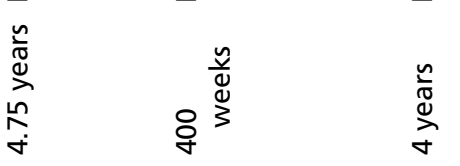

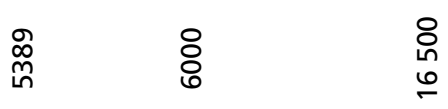

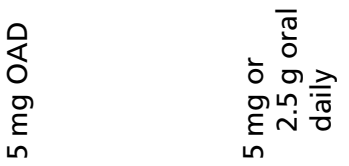

คัง

这岕

山

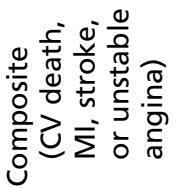

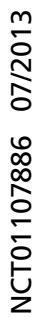

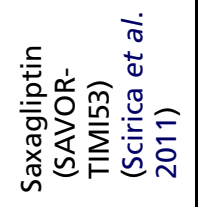


Association (NYHA) class I-III were randomized to vildagliptin $(n=128)$ or placebo $(n=126)$. By 52 weeks, the mean increase in the ejection fraction (EF) did not differ between groups while the mean HbA1c difference between vildagliptin and placebo at 16 weeks was $0.62 \%$ $(P<0.001)$. Unexpectedly, treatment was associated with increases in left ventricular (LV) end-diastolic volume $(P=0.007)$, end-systolic volume $(P=0.06)$, stroke volume $(P=0.002)$, and mortality (8.6 vs $3.2 \%)$, raising concerns regarding the safety of vildagliptin in heart failure patients. Unfortunately, the study was underpowered to properly evaluate safety, leaving open questions to be answered by the ongoing trials.

\section{Incretins and CV effects of weight loss}

GLP-1R activation in the hypothalamus reduces appetite and promotes satiety by inhibition of gastric emptying, leading to weight loss (Flint et al. 1998, Larsen et al. 2001). In patients with T2DM, the use of exenatide (Amori et al. 2007) and liraglutide (Vilsboll 2007) has been associated with significant weight loss. Similar results were confirmed in a study with non-diabetic, obese patients treated with liraglutide (Astrup et al. 2012). The weight-reducing effect of GLP-1 contributes to beneficial effect on CV risk factors such as lipid profile and BP (Flint et al. 1998, Larsen et al. 2001, Kenchaiah et al. 2002, Shibata et al. 2005, Horton et al. 2010) in addition to glycemic control. In experimental animal models, reduction of body weight in spontaneously hypertensive and heart failure-prone rats treated with native GLP-1 was seen in association with improvement of LV function, systemic metabolic parameters, and survival (Poornima et al. 2008). Similarly, a 5-week infusion of native GLP1 was associated with $\sim 5 \mathrm{~kg}$ weight reduction in patients with class III/IV NYHA heart failure (Sokos et al. 2006). Clinical trials with GLP-1R agonists and analogs in patients with T2DM have demonstrated reductions in BP in parallel with reductions in body weight (Varanasi et al. 2012). The extent to which weight reduction leads to $\mathrm{BP}$ reduction is difficult to discriminate in these clinical trials but underscores the fact that GLP-1 may have several and perhaps synergistic mechanisms of action to favorably influence the metabolic profile.

\section{CV effects of GLP-1 and GLP-1R agonists and analogs}

The human GLP-1R is a class B G-protein-coupled receptor expressed not only on pancreatic islet $\alpha$ and $\beta$ cells but also in the heart (Fig. 1A and B), kidney, brain, blood vessels,

Published by Bioscientifica Ltd http://joe.endocrinology-journals.org DOI: 10.1530/JOE-13-0195
(C) 2014 Society for Endocrinology Printed in Great Britain 

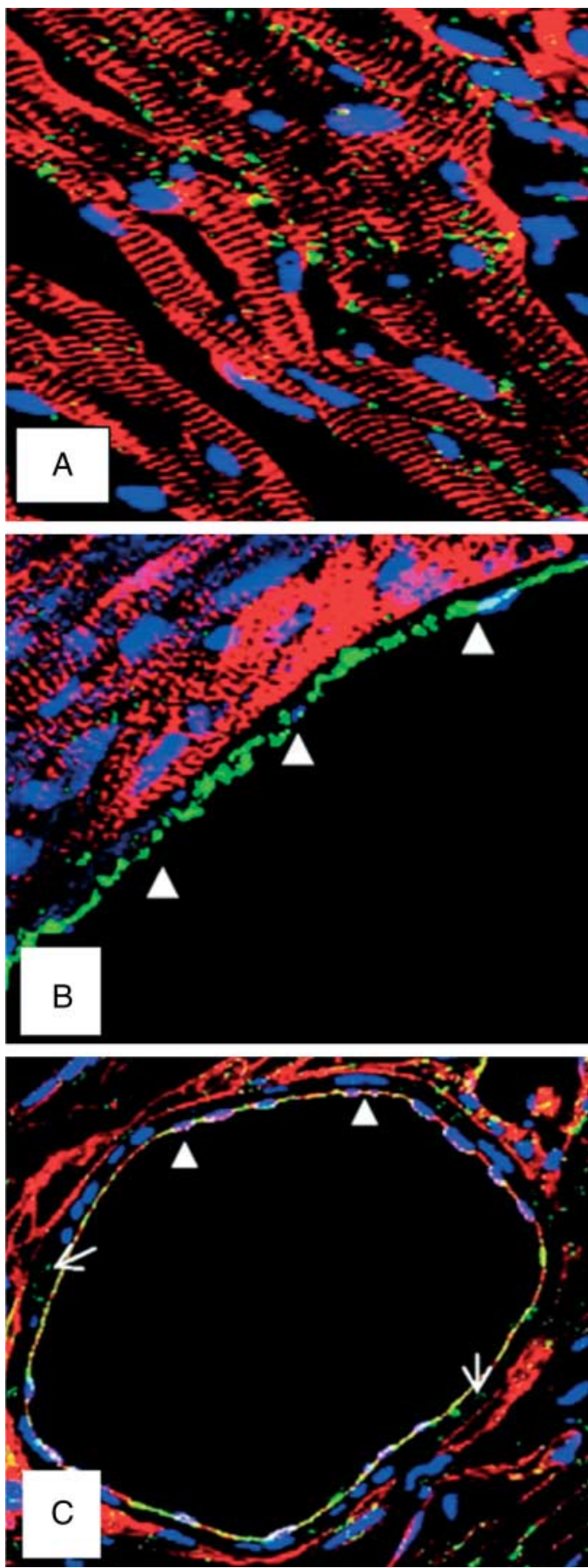

Figure 1

GLP-1R expression in mouse hearts. (A) Hearts labeled with anti-sarcomeric $\alpha$-actinin (red), anti-GLP-1R (green), and Hoechst nuclear stain (blue) revealed GLP-1R expression on cardiomyocytes, (B) endocardium (arrowheads),

(C) vascular endothelium, and smooth muscle cells (SMCs) (arrowheads and arrows respectively). (C) and $30 \mu \mathrm{mol} / \mathrm{l}$ ( $\mathrm{A}$ and $\mathrm{B}$ ). Modified, with permission, from Ban K, Noyan-Ashraf MH, Hoefer J, Bolz SS, Drucker DJ \& Husain M 2008 Cardioprotective and vasodilatory actions of glucagon-like peptide 1 receptor are mediated through both glucagon-like peptide 1 receptordependent and -independent pathways. Circulation 117 2340-2350. endothelial cells, and gastrointestinal tract (Bullock et al. 1996, Ban et al. 2008). Preclinical and clinical studies have elucidated some of the biological actions of the GLP-1R system on the heart and blood vessels independent of its actions on pancreatic islets and the subsequent improvement in glycemic control (Barragan et al. 1994, Zhao et al. 2006, Green et al. 2008).

\section{Effects on heart rate and $\mathrm{BP}$}

The mechanisms leading to reduced BP and changes in heart rate (HR) are not fully understood, but GLP-1's effects on BP and HR appear to be both species- (rodents vs other mammals) and preparation-specific (anesthetized vs conscious, isolated vs intact cardiac preparations) with differing effects depending on the duration of the GLP-1R activation and preexistence of comorbidities. Preclinical studies with GLP-1 analogs indicate that reduction in BP could be dependent on the autonomic nervous system (Bharucha et al. 2008), while a recent study indicates that GLP-1R activation promotes the secretion of atrial natriuretic peptide (ANP) and that a GLP-1R-dependent and ANP-dependent axis regulates BP (Kim et al. 2013). Similarly, both autonomic nervous system-dependent and -independent mechanisms have been suggested to lead to rises in HR (Gardiner et al. 2008).

Acute administration of GLP-1 and exendin-4 in rats increased BP and HR (Barragan et al. 1996), while a 7-day infusion of exendin- 4 resulted in reduction of BP in a rat model (Laugero et al. 2009). In healthy human subjects, infusion of native GLP-1 for $65 \mathrm{~min}$ had no effect on BP or on HR variability (Bharucha et al. 2008), while 48-h infusion in 15 non-diabetic patients with heart failure (NYHA class II/III) resulted in small increase in HR and diastolic BP (Halbirk et al. 2010). In contrast, in a 5-week infusion of native GLP-1 in 12 heart failure patients (NYHA class III/IV), there were no significant changes in the HR or BP, although the systemic vascular resistance was significantly lower in the treated group (Sokos et al. 2006). Thus, even in humans with heart failure, the effects of native GLP-1 on HR and BP vary with respect to severity of heart failure and duration of GLP-1 exposure.

The body of evidence examining the effects of GLP-1 agonists and analogs is more robust in patients with T2DM. A significant reduction in systolic BP was demonstrated after a 52-week treatment with exenatide in a randomized trial with T2DM patients (Buse et al. 2010). Similar results confirm the reduction in BP with exenatide therapy in a large retrospective analysis of patients with T2DM (Horton et al. 2010). Moreover, a

Published by Bioscientifica Ltd 
meta-analysis including 31 trials evaluating the effects of exenatide and liraglutide on BP confirmed a reduction in systolic pressure by $-1.79 \mathrm{mmHg}(-2.94$ to -0.64$)$ and $-2.39 \mathrm{mmHg}(-3.35$ to -1.42$)$ compared with placebo and active anti-diabetic drug therapy respectively (Robinson et al. 2013). Whether changes in BP were a consequence of the concomitant reduction in body weight remains to be determined definitively. In keeping with a direct anti-hypertensive effects is the finding that liraglutide significantly reduced systolic in T2DM (Gallwitz et al. 2010, Varanasi et al. 2012), before the significant weight loss was observed (Gallwitz et al. 2010).

In addition, small increases in HR have been reported in several clinical studies and recently compiled in a metaanalysis including 22 trials (Marre et al. 2009, Pratley et al. 2010, Buse et al. 2011, Nathanson et al. 2012, Robinson et al. 2013). GLP-1 agonists lead to an increase in HR of 1.86 beats/min (bpm; 0.85-2.87) and $1.9 \mathrm{bpm}(1.30-2.50)$ compared with placebo and active control respectively. HR rises were more evident for liraglutide than exenatide, and for exenatide long-acting release than exenatide twice daily (Robinson et al. 2013). The clinical relevance of those findings is still not fully understood and may be clarified by the ongoing CV safety trials (Table 2).

\section{Cardioprotective effects}

The cardioprotective effects of GLP-1 and GLP-1R agonists and analogs in ischemic heart disease have been supported by extensive studies of rodent models of ischemiareperfusion using isolated heart preparations (Bose et al. 2005a,b. Nikolaidis et al. 2005a, Zhao et al. 2006, Noyan-Ashraf et al. 2009, Timmers et al. 2009). The cardioprotective effects seem to be related to the elevation of intracellular calcium by a cAMP-activated PKA pathway (Xiao et al. 2011) and with the anti-apoptotic signaling and inhibition of mitochondrial permeability transition pore opening by the activation of the pro-survival reperfusion injury salvage kinase pathway (Hausenloy \& Yellon 2004, 2007). Indeed, GLP-1 (Nikolaidis et al. 2005a, Xiao et al. 2011), exendin-4 (Fineman et al. 2012), exenatide (Timmers et al. 2009), albiglutide (Bao et al. 2011), GLP-1-transferrin (Matsubara et al. 2011), and liraglutide (Noyan-Ashraf et al. 2009) improved postischemic contractile dysfunction and decreased infarct size in different in vivo animal models of ischemia and reperfusion. In a porcine model of ischemia-reperfusion, exenatide reduced infarct size by $40 \%$ and prevented further deterioration of systolic and diastolic function (Timmers et al. 2009). These findings were associated with reduced apoptosis and nuclear oxidative stress and improvement in myocardial glucose metabolism (Timmers et al. 2009). Moreover, GLP-1 administered to conscious dogs undergoing a 10-min coronary occlusion followed by $24 \mathrm{~h}$ of reperfusion enhanced recovery from myocardium stunning as demonstrated by the earlier and complete recovery of the regional wall motion in the treated animals (Fig. 2; Nikolaidis et al. 2005a). In addition, GLP-1 was associated with improvement in myocardium glucose uptake and isovolumic LV relaxation (Barragan et al. 1994).

It is worth of note that, positive findings are not universal as other animal studies were not able to demonstrate similar results (Kavianipour et al. 2003, Kristensen et al. 2009). In a porcine model of ischemiareperfusion, recombinant GLP-1 infusion improved myocardial glucose utilization but had no beneficial effects on infarct size or cardiac function (Kavianipour et al. 2003). Similarly, despite being associated with higher HR, treatment with liraglutide had neutral effects on infarct size and hemodynamics in a porcine model of ischemiareperfusion (Kristensen et al. 2009). These inconsistent results may be related to different doses, timing of administration, agents employed, and animal models

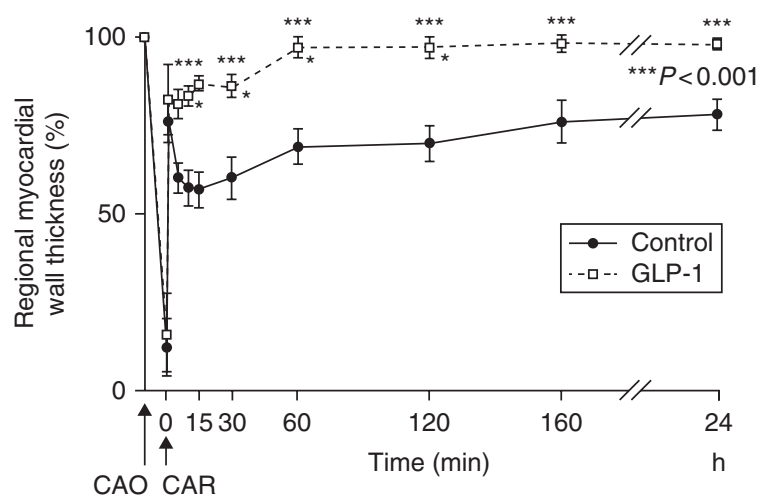

Figure 2

Regional post-ischemic contractile function recovery with GLP-1 in a canine model. Regional wall thickening responses to coronary artery occlusion and coronary artery reperfusion in a canine model. The differences in patterns of recovery of regional contractile function between the control (solid line) and GLP-1-treated animals (dotted lines) are illustrated by the significant dissociation between normalization of coronary flow and recovery of the respective posterior wall thickness, in the control group, consistent with myocardial stunning, even $24 \mathrm{~h}$ post-coronary artery reperfusion. In contrast, GLP-1-treated dogs demonstrated rapid and complete recovery of regional function in the ischemic zone over time. ${ }^{*} P<0.01$ vs baseline $* * * P<0.001$ vs control by ANOVA. CAO, coronary artery occlusion; CAR, coronary artery reperfusion. Modified, with permission, from Nikolaidis LA, Doverspike A, Hentosz T, Zourelias L, Shen YT, Elahi D \& Shannon RP 2005a Glucagon-like peptide-1 limits myocardial stunning following brief coronary occlusion and reperfusion in conscious canines. Journal of Pharmacology and Experimental Therapeutics 312 303-308. 
used, highlighting the need for further investigation, particularly in large-animal models.

Positive effects of native GLP-1 infusion in patients with acute myocardial infarction (MI) and LV dysfunction after successful reperfusion were demonstrated in a nonrandomized pilot study ( $n=21$; Nikolaidis et al. 2004b). In this study, 72-h infusion with GLP-1 significantly improved LVEF $(29 \pm 2-39 \pm 2 \% ; P<0.01)$, and wall motion score indices $(1.94 \pm 0.11-1.63 \pm 0.09 ; P<0.01)$ compared with control (Fig. $3 \mathrm{~A}$ and $\mathrm{B}$ respectively; Nikolaidis et al. 2004b). Furthermore, GLP-1 treatment was associated with significant reduction in hospital length-of-stay $(6.1 \pm 1.3$ vs $9.8 \pm 1.5$ days; $P<0.02)$ and in-hospital mortality (10 vs $27 \%$; Nikolaidis et al. 2004b). Supporting those results, native GLP-1 infusion reduced ischemic LV dysfunction and mitigated stunning in
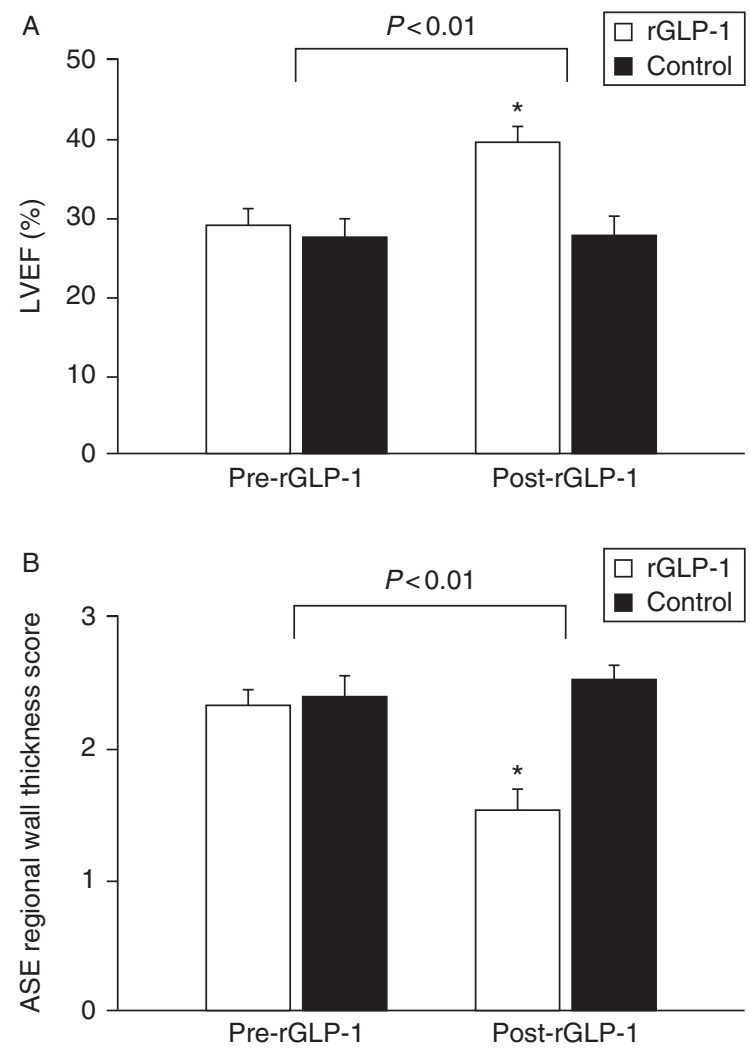

Figure 3

Effects of GLP-1 infusion on cardiac function in patients with acute myocardial infarction and left ventricular dysfunction. (A) Changes in LVEF after $72 \mathrm{~h}$ of rGLP-1 infusion (white bars) vs control subjects (black bars). (B) Changes in regional wall motion score at the per-infarct zone in rGLP-1treated patients vs control subjects. Results indicate left ventricular function improvement in the GLP-1-treated patients compared with the control group. Modified, with permission, from Nikolaidis LA, Mankad S, Sokos GG, Miske G, Shah A, Elahi D \& Shannon RP 2004b Effects of glucagon-like peptide- 1 in patients with acute myocardial infarction and left ventricular dysfunction after successful reperfusion. Circulation 109 962-965.
20 non-diabetic patients with normal LV function and single-vessel coronary disease within the left anterior descending artery undergoing elective percutaneous coronary intervention (PCI; Read et al. 2011).

The cardioprotective effects of $6 \mathrm{~h}$ infusion of exenatide initiated 15 minutes before reperfusion was evaluated in 172 patients with ST-segment elevation MI treated with primary PCI. A significantly larger salvage index was found in the exenatide group compared with the control group $(0.71 \pm 0.13$ vs $0.62 \pm 0.16 ; P=0.003$; Lonborg et al. $2012 b)$. However, absolute infarct size was not different nor was residual left ventricle systolic function (LVEF). Interestingly, a post-hoc analysis of the study demonstrated that in patients with shorter durations of chest pain $(\leq 132 \mathrm{~min}(n=74))$, treatment with exenatide was associated with smaller infarct size (8\% (Lonborg et al. 2012a) vs 11\% (interquartile range 7-17), $P=0.015$ ) even after adjusting for myocardial area at risk $(P=0.006)$. No difference was observed in infarct size in patients with longer durations of chest pain (>132 min; Lonborg et al. 2012a). Taken together, these data indicate that exenatide infusion at the time of reperfusion may reduce infarct size within a narrow clinical window of the first $2 \mathrm{~h}$ from the onset of chest pain.

\section{Impact on cardiac function}

Activation of GLP-1R has been associated with improvements in $\mathrm{CV}$ function in heart failure in preclinical (Nikolaidis et al. 2004a, Ceriello 2006, Bhashyam et al. 2010, Liu et al. 2010) and clinical settings (Sokos et al. 2006, Vilsboll 2007, Lonborg et al. 2012a). In a conscious, canine model of LV systolic dysfunction induced by rapid pacing, activation of p38 MAPK and nitric oxide (NO) synthase and an increase in GLUT1 expression led to an insulin-independent increase in myocardial glucose uptake, indicating a non-insulin-mediated mechanisms for CV benefits of GLP-1 (Bhashyam et al. 2010).

The beneficial effects of GLP-1 in the failing heart were also demonstrated in clinical settings. GLP-1 infusion for 5 weeks added to standard therapy in patients with and without diabetes and NYHA class III/IV heart failure led to improvement in LV systolic function, and exercise tolerance, as well as the 6-min walk distance, and quality of life. No changes were observed in the control group (Table 3; Sokos et al. 2006). Indeed, GLP-1 was also demonstrated to have potential to improve myocardial glucose metabolism and cardiac function in patients with heart failure and DM (Thrainsdottir et al. 2004). Interestingly, in a randomized, double-blind, crossover trial of 20 non-diabetic patients with HF NYHA class II/III, short-

Published by Bioscientifica Ltd 
Table 3 Safety and efficacy of sustained GLP-1 infusion in with advanced heart failure. GLP-1 infusion in patients with advanced systolic hear failure (NYHA class III-IV), including both diabetics and non-diabetics, was associated with improvement in LVEF, exercise tolerance, and quality of life

\begin{tabular}{|c|c|c|c|c|}
\hline & \multicolumn{2}{|c|}{ GLP-1 patients $(n=12)$} & \multicolumn{2}{|c|}{ Control patients $(n=9)$} \\
\hline & Baseline & 5 weeks & Baseline & 5 weeks \\
\hline LVEF (\%) & $21 \pm 3$ & $27 \pm 3^{*}$ & $21 \pm 4$ & $21 \pm 4$ \\
\hline VO2 m & $10.8 \pm 0.9$ & $13.9 \pm 0.6 *$ & $13.3 \pm 0.9$ & $13.0 \pm 1.0$ \\
\hline 6-min walk (m) & $232 \pm 15$ & $286 \pm 12^{*}$ & $233 \pm 21$ & $258 \pm 21$ \\
\hline Minn QOL & $64 \pm 4$ & $44 \pm 5 *$ & $52 \pm$ & $46 \pm 12$ \\
\hline BNP $(\mathrm{pg} / \mathrm{ml})$ & $289 \pm 90$ & $218 \pm 102$ & $296 \pm 129$ & $285 \pm 152$ \\
\hline
\end{tabular}

$* P<0.001$ vs baseline. LVEF, left ventricle systolic function; VO2 max, maximal oxygen consumption; 6-min walk, 6-min walk distance test; Minn QOL, Minnesota Living with Heart Failure Quality of Life Score; BNP, brain natriuretic peptide. Reproduced, with permission, from Sokos GG, Nikolaidis LA, Mankad S, Elahi D \& Shannon RP 2006 Glucagon-like peptide-1 infusion improves left ventricular ejection fraction and functional status in patients with chronic heart failure. Journal of Cardiac Failure 12 694-699.

term infusion of GLP-1 (over $48 \mathrm{~h}$ ) increased circulating insulin levels and reduced plasma glucose concentration but had no cardiac function benefits compared with control. This indicates that incretin-based therapy may be most appropriate in advanced heart failure and longterm therapy may be required in order to see the benefits (Halbirk et al. 2010).

\section{GLP-1R-independent CV effects of GLP-1}

Although GLP-1R seems to transduce most of the known GLP-1 actions in vivo, several studies have demonstrated that cells and tissues that do not express GLP-1R can also be affected by GLP-1 (Bullock et al. 1996, Abu-Hamdah et al. 2009). Moreover, GLP-1 primary metabolite GLP-1 (9-36) and its secondary metabolites (e.g. GLP-1 (28-36); Ban et al. 2008, Elahi et al. 2008) also seem to have effects. GLP-1 (9-36) does not interact with known GLP-1R and seems to act as a weak competitive antagonist of GLP-1R located in the $\beta$-cells and in the gastrointestinal tract (Kieffer \& Habener 1999). Although the literature indicates that most of the glucoregulatory effects of GLP-1 (9-36) are insulin-independent and occur in insulin resistance states (Elahi et al. 2008, Tomas et al. 2011), CV effects do not necessarily follow the same pattern. A school of thought is now emerging to suggest that the metabolites are not a product of degradation of the native peptide but rather a part of the full activation pathway of the incretin effect, resulting in additional CV benefits.

Ban et al. (2008) demonstrated that the vasodilatation and cardioprotection of GLP-1 (9-36) in a mouse model of ischemia-reperfusion injury was present even in the absence of functional GLP-1R. The authors proposed a NO/cGMP-dependent cardioprotective mechanism, supported by the finding of increased expression of cGMP and absence of effects upon NO synthase inhibition (Ban et al. 2008). In line with those results, a 48-h infusion of GLP-1 (9-36) in a model of pacing-induced heart failure in conscious dogs improved LV function, reduced systemic vascular resistance, and increased myocardial glucose uptake (Nikolaidis et al. 2005b) independent of the action of insulin. Functional improvements seen with continuous infusion of GLP-1 (9-36) paralleled the results using native GLP-1 in the same animal model, indicating that GLP-1 metabolites may play a key role in this setting (Nikolaidis et al. 2005b, Bhashyam et al. 2010; Fig. 4A, B, C and D). Although the data are promising, further studies are necessary to further elucidate the role of the GLP-1 metabolites as therapeutic agents in CVD. The work has considerable implications for use of these agents beyond glycemic control.

\section{CV effects of DPP-4 inhibitors}

DPP-4 is the first step in the breakdown of native GLP-1 (7-36) amide. Inhibition of DPP-4 became an attractive therapeutic target as such agents would prolong the circulating half-life of native GLP-1 (7-36) and prolong its insulinotropic effects. However, DPP-4 cleaves multiple peptides, many of which have demonstrated to have $\mathrm{CV}$ actions (Fig. 5; Drucker \& Nauck 2006, Ussher \& Drucker 2012), although prolonged circulating GLP-1 levels may be important in many of those actions, the circulating concentrations achieved in the plasma are threefold to fourfold lower than those with pharmacological doses of GLP-1R agonist or analogs.

Thus, attention has focused on other DPP-4 substrates that have recognized CV benefits. B-type (brain) natriuretic peptide 1-32 (BNP 1-32) is a peptide secreted by the ventricle and a key factor in regulating body fluid homeostasis and vascular tone (Ogawa et al. 1996, Boerrigter et al. 2007). Therefore, cleavage by DPP-4 leads to a reduction of diuretic and natriuretic actions and inhibition of vasodilatation (Boerrigter et al. 2007). Additionally, BNP seems to reduce cardiac remodeling after acute myocardial infarction (Moilanen et al. 2011, Palazzuoli et al. 2011), which could be another potential benefit of using DPP-4 inhibitors (DPP-4i). Although cardioprotection of BNP via DPP-4 inhibition was demonstrated in a porcine model of heart failure (Gomez et al. 2012), further studies are needed to clarify those interactions.

Published by Bioscientifica Ltd 
A

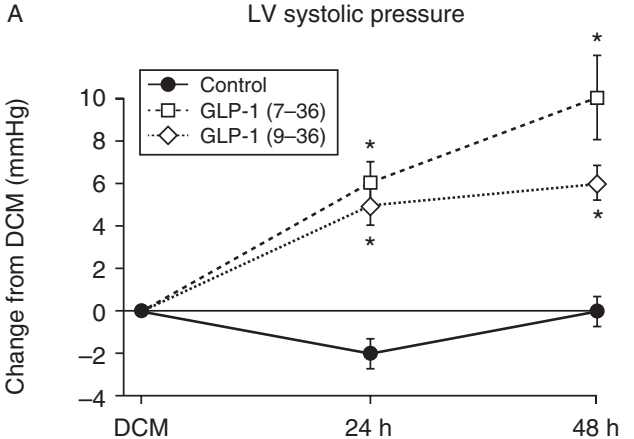

C

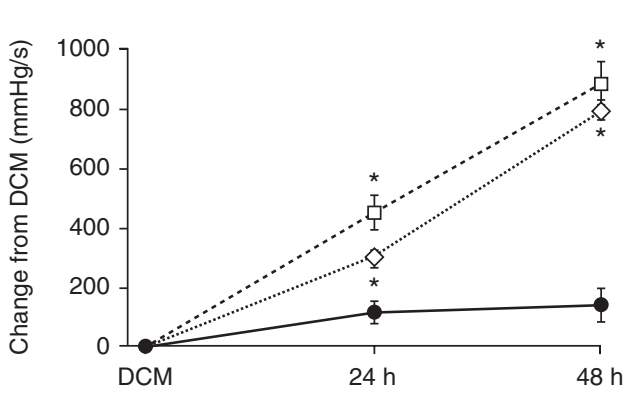

B

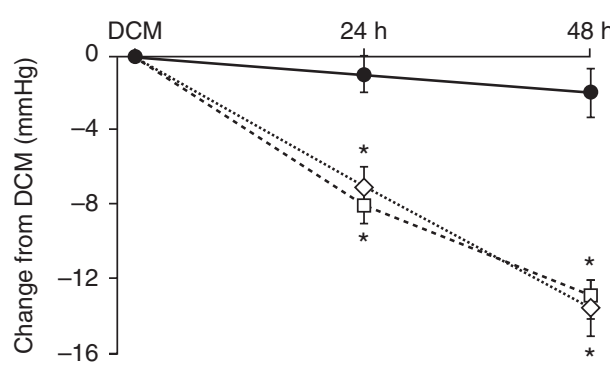

D

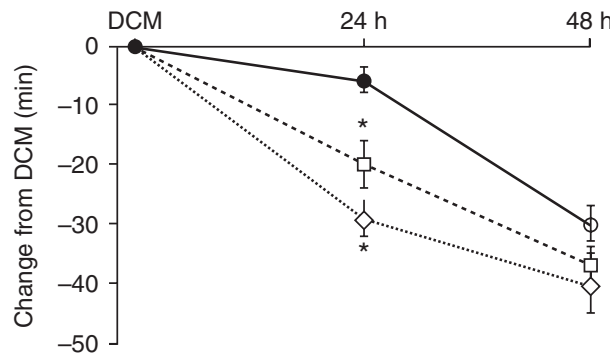

\section{Figure 4}

Positive effects of GLP-1 (7-36) and GLP-1 (9-36) on left ventricular function in conscious dogs with pacing-induced dilated cardiomyopathy. Effects of GLP-1 (7-36) ( $n=9$ dogs) or GLP-1 (9-36) ( $n=7$ dogs) on left ventricular pressures (A and B), contractility (C, LV dP/dt), and heart rate (D) in conscious dogs with pacing-induced dilated cardiomyopathy. Functional improvements were virtually identical with each form of the peptide compared with control (A, B and C), while there was no difference in the heart rate response, which decreased significantly in all three groups after

Stromal cell-derived factor- $1 \alpha(\operatorname{SDF} 1 \alpha)$ is a chemokine that promotes homing of endothelial progenitor cells to sites of injury and therefore promotes neoangiogenesis (Asahara et al. 1997). Because SDF1 $\alpha$ is cleaved by DPP-4, DPP-4 inhibition increases levels of circulating SDF1 $\alpha$. As a result, sitagliptin increased levels of circulating endothelial progenitor cells in T2DM patients (Fadini et al. 2010), while diprotin A in association with granulocyte colony-stimulating factor decreased infarct size and enhanced neovascularization, LVEF, and survival in a rodent model of MI (Zaruba et al. 2009). Besides the potential beneficial actions of BNP and SDF $1 \alpha$, other DPP-4 substrates may also have CV affects. Thus, while DPP-4 inhibition and GLP- 1 analogs may have similar CV profiles, they may be achieved through differing mechanisms.

\section{Effects on BP}

Sitagliptin reduced blood pleasure in a rodent model of metabolic syndrome (Ferreira et al. 2010). Discrepant
$48 \mathrm{~h}$ (D). DCM, dilated cardiomyopathy; LVEDP, left ventricular end-diastolic pressure. ${ }^{\star} P<0.05$ compared with response observed with saline control ( $n=7$ dogs). Reproduced, with permission, from Nikolaidis LA, Elahi D, Shen YT \& Shannon RP 2005b Active metabolite of GLP-1 mediates myocardial glucose uptake and improves left ventricular performance in conscious dogs with dilated cardiomyopathy. American Journal of Physiology. Heart and Circulatory Physiology 289 H2401-H2408.

results were found in a spontaneously hypertensive rat model, with benefit only observed in the young animals ( 5 vs 20 weeks old; Pacheco et al. 2011). Nevertheless, small clinical studies in non-diabetic (Mistry et al. 2008) and diabetic (Ogawa et al. 2011) hypertensive patients treated with sitagliptin identified an association with reduction of $\mathrm{BP}$ in the absence of weight loss. Similar results were also observed in larger studies in T2DM patients (Bergenstal et al. 2010, Russell-Jones et al. 2012). Notably, these effects on BP occur in the absence of significant weight loss.

\section{DPP-4 inhibition in ischemic heart disease}

DPP-4 inhibitors probably share some GLP-1R-dependent cardioprotective mechanisms previously described (Ogawa et al. 2011), although it should be noted that DPP-4 inhibitors yield physiological not pharmacological levels of circulating GLP-1. Indeed, preclinical studies demonstrate cardioprotection associated with DPP4-1 therapy in in vivo models (Ye et al. 2010, Huisamen et al. 2011,

Published by Bioscientifica Ltd 


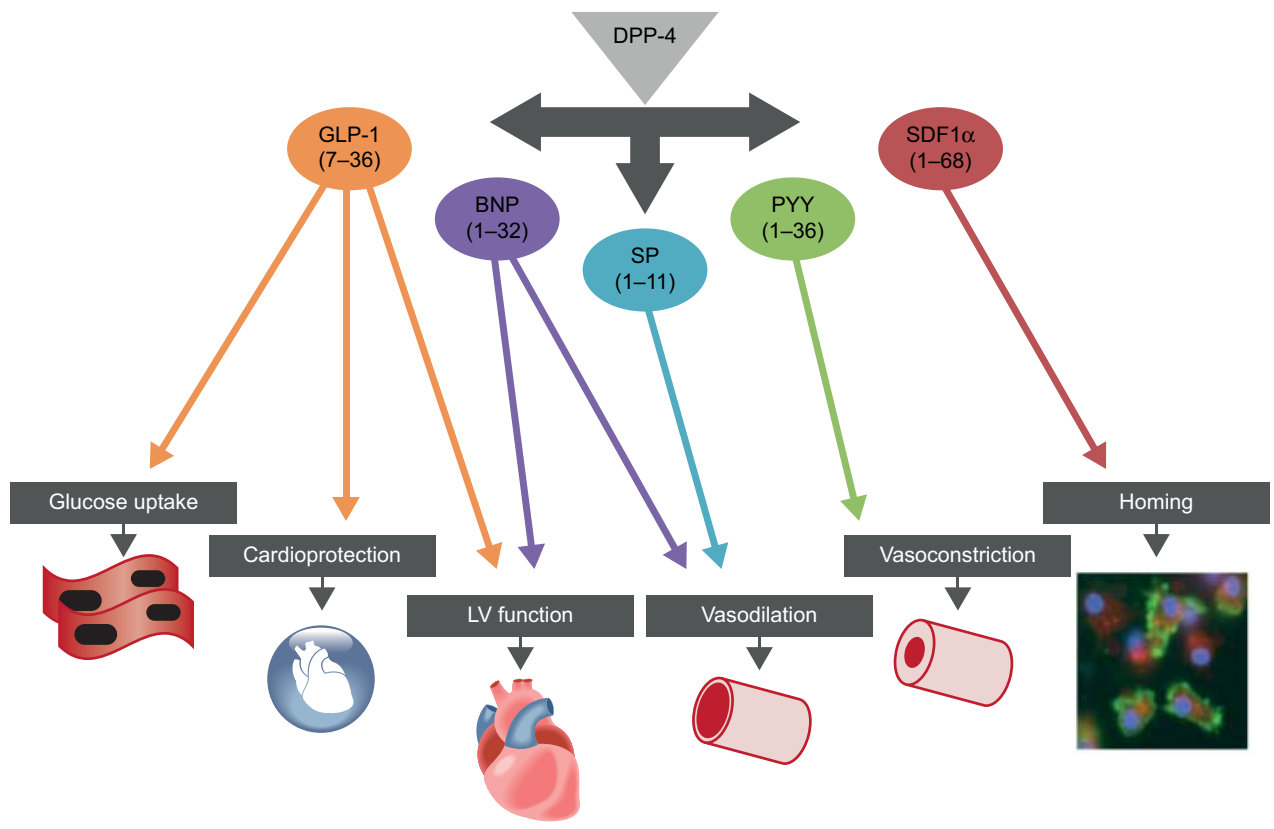

\section{Figure 5}

DPP-4 substrates that directly or indirectly regulate cardiovascular function. Multiple DPP-4 substrates have been identified that act on multiple peripheral tissues that influence the cardiovascular system.

Hocher et al. 2013). Moreover, data indicates that enhanced angiogenesis may also play a role in the cardioprotection as demonstrated by a study addressing the adjunctive affect of SDF1 $\alpha$ (Zaruba et al. 2009). In clinical settings, the DPP-4i sitagliptin improved global cardiac performance and attenuated post-ischemic stunning in 14 patients with coronary artery disease during dobutamine stress echocardiography (Read et al. 2010). More recently, the preliminary results of the TIMI 53/Savor trial with saxagliptin indicate that while safe, this DPP-4i did not reduce composite CV events of CV death, MI, or stroke. The complete results of the study will be released shortly.

\section{Role of DPP-4 inhibition in cardiac function}

Few preclinical studies have directly addressed the role of DPP-4 inhibition in heart failure models. Sitagliptin increased stroke volume and reduced HR in a porcine model of pacing-induced heart failure (Gomez et al. 2012). On the other hand, vildagliptin had neutral effects on cardiac function in a rat model of ischemic cardiomyopathy (Yin et al. 2011). As previously described, the first clinical trial looking into $\mathrm{CV}$ effects of vildagliptin in patients with diabetes and NYHA class I-III $(n=254)$ confirmed the neutral effects in cardiac function measured by the mean increase in $\mathrm{EF}$ in the treatment group compared with the control group (4.1 vs 3.5\% respectively, $P=0.67)$ and raised safety concerns related to a potential negative effect on LV compliance and an increase in noncardiac mortality (McMurray 2013). Taken together, these early data indicate that the CV profile of DPP-4 inhibitors may vary from the CV profile of the native GLP-1 peptide and GLP-1R agonists and analogs.

\section{Summary}

Incretin-based therapies have emerged as potent antidiabetic agents of particular clinical interest due to the emerging evidence that they are associated with $\mathrm{CV}$ benefits. Currently, over 120000 patients are enrolled in CV outcome trials with incretin-based therapies designed to demonstrate safety and efficacy. Specifically, most of these trials have primary major adverse cardiac event (MACE) outcomes of CV death, MI, or need for revascularization. As such, we stand on the verge of learning a great deal about the ability of incretin-based therapies to improve CV outcomes in T2DM. Nonetheless, much remains to be learned with respect to this promising class of agents. First, it is not certain whether this is a class effect or whether there are differences between types of incretin-based therapies (native peptide vs GLP-1 long-acting analogs vs DPP-4 inhibitors). A related question bears on whether the metabolites contribute

Published by Bioscientifica Ltd 
to CV benefits. Secondly, it is unclear whether incretinbased therapies have $\mathrm{CV}$ benefits that extend beyond T2DM. Finally, the use of incretin-based therapies as metabolic modulators in heart failure represents a new therapeutic approach in this important CV domain. Time and careful study will tell whether these agents will establish a new therapeutic paradigm.

\section{Declaration of interest}

The authors declare that there is no conflict of interest that could be perceived as prejudicing the impartiality of the review reported.

\section{Funding}

Dr R P S is the founder of Ventrigen, LLC, and has received research support from Pfizer and Astra Zeneca/Bristol Myers Squibb for the study of incretins and DPP-4 inhibitors in CV disease states in animals. No industry-based products or support were provided for these studies. Dr R P S holds USA Patent 7,182,822, the use of GLP-1 for the treatment of LV systolic dysfunction, and USA provisional patent 6/1515390 entitled the Methods and Compositions for Inhibiting Delayed Graft Function. Dr F S A holds a USA provisional patent 13/809,154 entitled Use of Interleukin-15 to treat Cardiovascular Diseases.

\section{References}

Abu-Hamdah R, Rabiee A, Meneilly GS, Shannon RP, Andersen DK \& Elahi D 2009 Clinical review: the extrapancreatic effects of glucagon-like peptide-1 and related peptides. Journal of Clinical Endocrinology and Metabolism 94 1843-1852. (doi:10.1210/jc.2008-1296)

Addison D \& Aguilar D 2011 Diabetes and cardiovascular disease: the potential benefit of incretin-based therapies. Current Atherosclerosis Reports 13 115-122. (doi:10.1007/s11883-010-0153-0)

Amori RE, Lau J \& Pittas AG 2007 Efficacy and safety of incretin therapy in type 2 diabetes: systematic review and meta-analysis. Journal of the American Medical Association 298 194-206. (doi:10.1001/jama.298. 2.194)

Asahara T, Murohara T, Sullivan A, Silver M, van der Zee R, Li T, Witzenbichler B, Schatteman G \& Isner JM 1997 Isolation of putative progenitor endothelial cells for angiogenesis. Science 275 964-967. (doi:10.1126/science.275.5302.964)

Astrup A, Carraro R, Finer N, Harper A, Kunesova M, Lean ME, Niskanen L, Rasmussen MF, Rissanen A, Rossner S et al. 2012 Safety, tolerability and sustained weight loss over 2 years with the once-daily human GLP1 analog, liraglutide. International Journal of Obesity 36 843-854. (doi:10.1038/ijo.2011.158)

Ban K, Noyan-Ashraf MH, Hoefer J, Bolz SS, Drucker DJ \& Husain M 2008 Cardioprotective and vasodilatory actions of glucagon-like peptide 1 receptor are mediated through both glucagon-like peptide 1 receptordependent and -independent pathways. Circulation 117 2340-2350. (doi:10.1161/CIRCULATIONAHA.107.739938)

Bao W, Aravindhan K, Alsaid H, Chendrimada T, Szapacs M, Citerone DR, Harpel MR, Willette RN, Lepore JJ \& Jucker BM 2011 Albiglutide, a long lasting glucagon-like peptide- 1 analog, protects the rat heart against ischemia/reperfusion injury: evidence for improving cardiac metabolic efficiency. PLoS ONE 6 e23570. (doi:10.1371/journal.pone.0023570)

Barragan JM, Rodriguez RE \& Blazquez E 1994 Changes in arterial blood pressure and heart rate induced by glucagon-like peptide-1-(7-36) amide in rats. American Journal of Physiology 266 E459-E466.

http://joe.endocrinology-journals.org DOI: 10.1530/JOE-13-0195
(C) 2014 Society for Endocrinology Printed in Great Britain
Barragan JM, Rodriguez RE, Eng J \& Blazquez E 1996 Interactions of exendin-(9-39) with the effects of glucagon-like peptide-1-(7-36) amide and of exendin- 4 on arterial blood pressure and heart rate in rats. Regulatory Peptides 67 63-68. (doi:10.1016/S0167-0115(96)00113-9)

Bergenstal RM, Wysham C, Macconell L, Malloy J, Walsh B, Yan P, Wilhelm K, Malone J, Porter LE \& Group D-S 2010 Efficacy and safety of exenatide once weekly versus sitagliptin or pioglitazone as an adjunct to metformin for treatment of type 2 diabetes (DURATION-2): a randomised trial. Lancet 376 431-439. (doi:10.1016/S0140-6736 (10)60590-9)

Bharucha AE, Charkoudian N, Andrews CN, Camilleri M, Sletten D, Zinsmeister AR \& Low PA 2008 Effects of glucagon-like peptide-1, yohimbine, and nitrergic modulation on sympathetic and parasympathetic activity in humans. American Journal of Physiology. Regulatory, Integrative and Comparative Physiology 295 R874-R880. (doi:10.1152/ ajpregu.00153.2008)

Bhashyam S, Fields AV, Patterson B, Testani JM, Chen L, Shen YT \& Shannon RP 2010 Glucagon-like peptide-1 increases myocardial glucose uptake via p38 $\alpha$ MAP kinase-mediated, nitric oxide-dependent mechanisms in conscious dogs with dilated cardiomyopathy. Circulation. Heart Failure 3 512-521. (doi:10.1161/CIRCHEARTFAILURE.109. 900282)

Boerrigter G, Costello-Boerrigter LC, Harty GJ, Lapp H \& Burnett JC Jr 2007 Des-serine-proline brain natriuretic peptide 3-32 in cardiorenal regulation. American Journal of Physiology. Regulatory, Integrative and Comparative Physiology 292 R897-R901. (doi:10.1152/ajpregu.00569. 2006)

Booth GL, Kapral MK, Fung K \& Tu JV 2006 Recent trends in cardiovascular complications among men and women with and without diabetes. Diabetes Care 29 32-37. (doi:10.2337/diacare.29.01.06.dc05-0776)

Bose AK, Mocanu MM, Carr RD, Brand CL \& Yellon DM 2005a Glucagonlike peptide 1 can directly protect the heart against ischemia/reperfusion injury. Diabetes 54 146-151. (doi:10.2337/diabetes.54.1.146)

Bose AK, Mocanu MM, Carr RD \& Yellon DM 2005b Glucagon like peptide- 1 is protective against myocardial ischemia/reperfusion injury when given either as a preconditioning mimetic or at reperfusion in an isolated rat heart model. Cardiovascular Drugs and Therapy 19 9-11. (doi:10.1007/s10557-005-6892-4)

Bullock BP, Heller RS \& Habener JF 1996 Tissue distribution of messenger ribonucleic acid encoding the rat glucagon-like peptide-1 receptor. Endocrinology 137 2968-2978. (doi:10.1210/en.137.7.2968)

Buse JB, Drucker DJ, Taylor KL, Kim T, Walsh B, Hu H, Wilhelm K, Trautmann M, Shen LZ, Porter LE et al. 2010 DURATION-1: exenatide once weekly produces sustained glycemic control and weight loss over 52 weeks. Diabetes Care 33 1255-1261. (doi:10.2337/dc09-1914)

Buse JB, Bergenstal RM, Glass LC, Heilmann CR, Lewis MS, Kwan AY, Hoogwerf BJ \& Rosenstock J 2011 Use of twice-daily exenatide in basal insulin-treated patients with type 2 diabetes: a randomized, controlled trial. Annals of Internal Medicine 154 103-112. (doi:10.7326/0003-4819. 154-2-201101180-00300)

Ceriello A 2006 Postprandial hyperglycemia and cardiovascular complications of diabetes. Journées Annuelles de Diabétologie de l'Hôtel-Dieu 75-78.

Cernea S \& Raz I 2011 Therapy in the early stage: incretins. Diabetes Care 34(Suppl 2) S264-S271. (doi:10.2337/dc11-s223)

Control G, Turnbull FM, Abraira C, Anderson RJ, Byington RP, Chalmers JP, Duckworth WC, Evans GW, Gerstein HC, Holman RR et al. 2009 Intensive glucose control and macrovascular outcomes in type 2 diabetes. Diabetologia 52 2288-2298. (doi:10.1007/s00125-009-1470-0)

Deacon CF, Johnsen AH \& Holst JJ 1995 Degradation of glucagon-like peptide- 1 by human plasma in vitro yields an N-terminally truncated peptide that is a major endogenous metabolite in vivo. Journal of Clinical Endocrinology and Metabolism 80 952-957. (doi:10.1210/jc.80.3.952)

Drucker DJ 2006 The biology of incretin hormones. Cell Metabolism 3 153-165. (doi:10.1016/j.cmet.2006.01.004)

Published by Bioscientifica Ltd 
Drucker DJ \& Nauck MA 2006 The incretin system: glucagon-like peptide-1 receptor agonists and dipeptidyl peptidase-4 inhibitors in type 2 diabetes. Lancet 368 1696-1705. (doi:10.1016/S0140-6736(06)69705-5)

Elahi D, Egan JM, Shannon RP, Meneilly GS, Khatri A, Habener JF \& Andersen DK 2008 GLP-1 (9-36) amide cleavage product of GLP-1 (7-36) amide, is a glucoregulatory peptide. Obesity 16 1501-1509. (doi:10.1038/oby.2008.229)

Fadini GP, Boscaro E, Albiero M, Menegazzo L, Frison V, de Kreutzenberg S, Agostini C, Tiengo A \& Avogaro A 2010 The oral dipeptidyl peptidase-4 inhibitor sitagliptin increases circulating endothelial progenitor cells in patients with type 2 diabetes: possible role of stromal-derived factor- $1 \alpha$. Diabetes Care 33 1607-1609. (doi:10.2337/dc10-0187)

Fakhoury WK, Lereun C \& Wright D 2010 A meta-analysis of placebocontrolled clinical trials assessing the efficacy and safety of incretinbased medications in patients with type 2 diabetes. Pharmacology 86 44-57. (doi:10.1159/000314690)

Ferreira L, Teixeira-de-Lemos E, Pinto F, Parada B, Mega C, Vala H, Pinto R, Garrido P, Sereno J, Fernandes R et al. 2010 Effects of sitagliptin treatment on dysmetabolism, inflammation, and oxidative stress in an animal model of type 2 diabetes (ZDF rat). Mediators of Inflammation 2010 592760. (doi:10.1155/2010/592760)

Fineman MS, Cirincione BB, Maggs D \& Diamant M 2012 GLP-1 based therapies: differential effects on fasting and postprandial glucose. Diabetes, Obesity \& Metabolism 14 675-688. (doi:10.1111/j.1463-1326. 2012.01560.x)

Flint A, Raben A, Astrup A \& Holst JJ 1998 Glucagon-like peptide 1 promotes satiety and suppresses energy intake in humans. Journal of Clinical Investigation 101 515-520. (doi:10.1172/JCI990)

Fox CS, Coady S, Sorlie PD, Levy D, Meigs JB, D'Agostino RB Sr, Wilson PW \& Savage PJ 2004 Trends in cardiovascular complications of diabetes. Journal of the American Medical Association 292 2495-2499. (doi:10.1001/jama.292.20.2495)

Gaebler JA, Soto-Campos G, Alperin P, Cohen M, Blickensderfer A, Wintle M, Maggs D, Hoogwerf B, Han J et al. 2012 Health and economic outcomes for exenatide once weekly, insulin, and pioglitazone therapies in the treatment of type 2 diabetes: A simulation analysis. Vascular Health and Risk Management 8 255-264. (doi:10.2147/ VHRM.S28744)

Gallwitz B, Vaag A, Falahati A \& Madsbad S 2010 Adding liraglutide to oral antidiabetic drug therapy: onset of treatment effects over time. International Journal of Clinical Practice 64 267-276. (doi:10.1111/ j.1742-1241.2009.02265.x)

Gardiner SM, March JE, Kemp PA \& Bennett T 2008 Autonomic nervous system-dependent and -independent cardiovascular effects of exendin-4 infusion in conscious rats. British Journal of Pharmacology 154 60-71. (doi:10.1038/bjp.2008.75)

Gomez N, Touihri K, Matheeussen V, Mendes Da Costa A, Mahmoudabady M, Mathieu M, Baerts L, Peace A, Lybaert P, Scharpe S et al. 2012 Dipeptidyl peptidase IV inhibition improves cardiorenal function in overpacinginduced heart failure. European Journal of Heart Failure 14 14-21. (doi:10.1093/eurjhf/hfr146)

Green BD, Hand KV, Dougan JE, McDonnell BM, Cassidy RS \& Grieve DJ 2008 GLP-1 and related peptides cause concentration-dependent relaxation of rat aorta through a pathway involving KATP and cAMP. Archives of Biochemistry and Biophysics 478 136-142. (doi:10.1016/ j.abb.2008.08.001)

Halbirk M, Norrelund H, Moller N, Holst JJ, Schmitz O, Nielsen R, NielsenKudsk JE, Nielsen SS, Nielsen TT, Eiskjaer H et al. 2010 Cardiovascular and metabolic effects of 48-h glucagon-like peptide-1 infusion in compensated chronic patients with heart failure. American Journal of Physiology. Heart and Circulatory Physiology 298 H1096-H1102. (doi:10.1152/ajpheart.00930.2009)

Hausenloy DJ \& Yellon DM 2004 New directions for protecting the heart against ischaemia-reperfusion injury: targeting the reperfusion injury salvage kinase (RISK)-pathway. Cardiovascular Research 61 448-460. (doi:10.1016/j.cardiores.2003.09.024)
Hausenloy DJ \& Yellon DM 2007 Reperfusion injury salvage kinase signalling: taking a RISK for cardioprotection. Heart Failure Reviews 12 217-234. (doi:10.1007/s10741-007-9026-1)

Herzlinger S \& Horton ES 2013 Extraglycemic effects of GLP-1-based therapeutics: addressing metabolic and cardiovascular risks associated with type 2 diabetes. Diabetes Research and Clinical Practice 100 1-10. (doi:10.1016/j.diabres.2012.11.009)

Hocher B, Sharkovska Y, Mark M, Klein T \& Pfab T 2013 The novel DPP-4 inhibitors linagliptin and BI 14361 reduce infarct size after myocardial ischemia/reperfusion in rats. International Journal of Cardiology 167 87-93. (doi:10.1016/j.ijcard.2011.12.007)

Horton ES, Silberman C, Davis KL \& Berria R 2010 Weight loss, glycemic control, and changes in cardiovascular biomarkers in patients with type 2 diabetes receiving incretin therapies or insulin in a large cohort database. Diabetes Care 33 1759-1765. (doi:10.2337/dc09-2062)

Huisamen B, Genis A, Marais E \& Lochner A 2011 Pre-treatment with a DPP-4 inhibitor is infarct sparing in hearts from obese, pre-diabetic rats. Cardiovascular Drugs and Therapy 25 13-20. (doi:10.1007/s10557-0106271-7)

Kavianipour M, Ehlers MR, Malmberg K, Ronquist G, Ryden L, Wikstrom G \& Gutniak M 2003 Glucagon-like peptide-1 (7-36) amide prevents the accumulation of pyruvate and lactate in the ischemic and nonischemic porcine myocardium. Peptides 24 569-578. (doi:10.1016/ S0196-9781(03)00108-6)

Kenchaiah S, Evans JC, Levy D, Wilson PW, Benjamin EJ, Larson MG, Kannel WB \& Vasan RS 2002 Obesity and the risk of heart failure. New England Journal of Medicine 347 305-313. (doi:10.1056/NEJMoa020245)

Kieffer TJ \& Habener JF 1999 The glucagon-like peptides. Endocrine Reviews 20 876-913. (doi:10.1210/er.20.6.876)

Kim M, Platt MJ, Shibasaki T, Quaggin SE, Backx PH, Seino S, Simpson JA \& Drucker DJ 2013 GLP-1 receptor activation and Epac2 link atrial natriuretic peptide secretion to control of blood pressure. Nature Medicine 19 567-575. (doi:10.1038/nm.3128)

Kristensen J, Mortensen UM, Schmidt M, Nielsen PH, Nielsen TT \& Maeng M 2009 Lack of cardioprotection from subcutaneously and preischemic administered liraglutide in a closed chest porcine ischemia reperfusion model. BMC Cardiovascular Disorders 931. (doi:10.1186/1471-2261-9-31)

Larsen PJ, Fledelius C, Knudsen LB \& Tang-Christensen M 2001 Systemic administration of the long-acting GLP-1 derivative NN2211 induces lasting and reversible weight loss in both normal and obese rats. Diabetes 50 2530-2539. (doi:10.2337/diabetes.50.11.2530)

Laugero KD, Stonehouse AH, Guss S, Landry J, Vu C \& Parkes DG 2009 Exenatide improves hypertension in a rat model of the metabolic syndrome. Metabolic Syndrome and Related Disorders $7327-334$. (doi:10.1089/met.2008.0095)

Li Y, Hansotia T, Yusta B, Ris F, Halban PA \& Drucker DJ 2003 Glucagon-like peptide-1 receptor signaling modulates $\beta$ cell apoptosis. Journal of Biological Chemistry 278 471-478. (doi:10.1074/ jbc.M209423200)

Liu Q, Anderson C, Broyde A, Polizzi C, Fernandez R, Baron A \& Parkes DG 2010 Glucagon-like peptide-1 and the exenatide analogue AC3174 improve cardiac function, cardiac remodeling, and survival in rats with chronic heart failure. Cardiovascular Diabetology 9 76. (doi:10.1186/ 1475-2840-9-76)

Lonborg J, Kelbaek H, Vejlstrup N, Botker HE, Kim WY, Holmvang L, Jorgensen E, Helqvist S, Saunamaki K, Terkelsen CJ et al. 2012a Exenatide reduces final infarct size in patients with ST-segmentelevation myocardial infarction and short-duration of ischemia. Circulation. Cardiovascular Interventions 5 288-295. (doi:10.1161/ CIRCINTERVENTIONS.112.968388)

Lonborg J, Vejlstrup N, Kelbaek H, Botker HE, Kim WY, Mathiasen AB, Jorgensen E, Helqvist S, Saunamaki K, Clemmensen P et al. $2012 b$ Exenatide reduces reperfusion injury in patients with ST-segment elevation myocardial infarction. European Heart Journal 33 1491-1499. (doi:10.1093/eurheartj/ehr309) 
Marre M, Shaw J, Brandle M, Bebakar WM, Kamaruddin NA, Strand J, Zdravkovic M, Le Thi TD, Colagiuri S \& LEAD-1 SU study group 2009 Liraglutide, a once-daily human GLP-1 analogue, added to a sulphonylurea over 26 weeks produces greater improvements in glycaemic and weight control compared with adding rosiglitazone or placebo in subjects with type 2 diabetes (LEAD-1 SU). Diabetic Medicine 26 268-278. (doi:10.1111/j.1464-5491.2009.02666.x)

Matsubara M, Kanemoto S, Leshnower BG, Albone EF, Hinmon R, Plappert T, Gorman JH III \& Gorman RC 2011 Single dose GLP-1-Tf ameliorates myocardial ischemia/reperfusion injury. Journal of Surgical Research $\mathbf{1 6 5}$ 38-45. (doi:10.1016/j.jss.2009.03.016)

McMurray JJ 2013 The Vidagliptin in Ventricular Dysfunction Diabetes (VIVIDD) trial. In Heart Failure Congress. Lisbon: European Society of Cardiology. Abstract 99.

Mistry GC, Maes AL, Lasseter KC, Davies MJ, Gottesdiener KM, Wagner JA \& Herman GA 2008 Effect of sitagliptin, a dipeptidyl peptidase-4 inhibitor, on blood pressure in nondiabetic patients with mild to moderate hypertension. Journal of Clinical Pharmacology 48 592-598. (doi:10.1177/0091270008316885)

Moilanen AM, Rysa J, Mustonen E, Serpi R, Aro J, Tokola H, Leskinen H, Manninen A, Levijoki J, Vuolteenaho O et al. 2011 Intramyocardial BNP gene delivery improves cardiac function through distinct contextdependent mechanisms. Circulation. Heart Failure 4 483-495. (doi:10.1161/CIRCHEARTFAILURE.110.958033)

Monami M, Dicembrini I, Martelli D \& Mannucci E 2011 Safety of dipeptidyl peptidase-4 inhibitors: a meta-analysis of randomized clinical trials. Current Medical Research and Opinion 27(Suppl 3) 57-64. (doi:10.1185/03007995.2011.602964)

Nathanson D, Ullman B, Lofstrom U, Hedman A, Frick M, Sjoholm A \& Nystrom T 2012 Effects of intravenous exenatide in type 2 diabetic patients with congestive heart failure: a double-blind, randomised controlled clinical trial of efficacy and safety. Diabetologia 55 926-935. (doi:10.1007/s00125-011-2440-x)

Nikolaidis LA, Elahi D, Hentosz T, Doverspike A, Huerbin R, Zourelias L, Stolarski C, Shen YT \& Shannon RP 2004a Recombinant glucagon-like peptide-1 increases myocardial glucose uptake and improves left ventricular performance in conscious dogs with pacing-induced dilated cardiomyopathy. Circulation 110 955-961. (doi:10.1161/01.CIR. 0000139339.85840.DD)

Nikolaidis LA, Mankad S, Sokos GG, Miske G, Shah A, Elahi D \& Shannon RP 2004b Effects of glucagon-like peptide-1 in patients with acute myocardial infarction and left ventricular dysfunction after successful reperfusion. Circulation 109 962-965. (doi:10.1161/01.CIR. 0000120505.91348.58)

Nikolaidis LA, Doverspike A, Hentosz T, Zourelias L, Shen YT, Elahi D \& Shannon RP 2005a Glucagon-like peptide-1 limits myocardial stunning following brief coronary occlusion and reperfusion in conscious canines. Journal of Pharmacology and Experimental Therapeutics $\mathbf{3 1 2}$ 303-308. (doi:10.1124/jpet.104.073890)

Nikolaidis LA, Elahi D, Shen YT \& Shannon RP 2005b Active metabolite of GLP-1 mediates myocardial glucose uptake and improves left ventricular performance in conscious dogs with dilated cardiomyopathy. American Journal of Physiology. Heart and Circulatory Physiology 289 H2401-H2408. (doi:10.1152/ajpheart.00347.2005)

Nissen SE \& Wolski K 2007 Effect of rosiglitazone on the risk of myocardial infarction and death from cardiovascular causes. New England Journal of Medicine 356 2457-2471. (doi:10.1056/NEJMoa072761)

Noyan-Ashraf MH, Momen MA, Ban K, Sadi AM, Zhou YQ, Riazi AM, Baggio LL, Henkelman RM, Husain M \& Drucker DJ 2009 GLP-1R agonist liraglutide activates cytoprotective pathways and improves outcomes after experimental myocardial infarction in mice. Diabetes $\mathbf{5 8}$ 975-983. (doi:10.2337/db08-1193)

Ogawa T, Linz W, Stevenson M, Bruneau BG, Kuroski de Bold ML, Chen JH, Eid H, Scholkens BA \& de Bold AJ 1996 Evidence for load-dependent and load-independent determinants of cardiac natriuretic peptide production. Circulation 93 2059-2067. (doi:10.1161/01.CIR.93.11. 2059)

Ogawa S, Ishiki M, Nako K, Okamura M, Senda M, Mori T \& Ito S 2011 Sitagliptin, a dipeptidyl peptidase- 4 inhibitor, decreases systolic blood pressure in Japanese hypertensive patients with type 2 diabetes. Tohoku Journal of Experimental Medicine 223 133-135. (doi:10.1620/ tjem.223.133)

Pacheco BP, Crajoinas RO, Couto GK, Davel AP, Lessa LM, Rossoni LV \& Girardi AC 2011 Dipeptidyl peptidase IV inhibition attenuates blood pressure rising in young spontaneously hypertensive rats. Journal of Hypertension 29 520-528. (doi:10.1097/HJH.0b013e328341939d)

Palazzuoli A, Antonelli G, Quatrini I \& Nuti R 2011 Natriuretic peptides in heart failure: where we are, where we are going. Internal and Emergency Medicine 6 63-68. (doi:10.1007/s11739-010-0438-x)

Perk J, De Backer G, Gohlke H, Graham I, Reiner Z, Verschuren WM, Albus C, Benlian P, Boysen G, Cifkova R et al. 2012 European guidelines on cardiovascular disease prevention in clinical practice (version 2012): the fifth joint task force of the European society of cardiology and other societies on cardiovascular disease prevention in clinical practice (constituted by representatives of nine societies and by invited experts). International Journal of Behavioral Medicine 19 403-488. (doi:10.1007/s12529-012-9242-5)

Poornima I, Brown SB, Bhashyam S, Parikh P, Bolukoglu H \& Shannon RP 2008 Chronic glucagon-like peptide-1 infusion sustains left ventricular systolic function and prolongs survival in the spontaneously hypertensive, heart failure-prone rat. Circulation. Heart Failure 1 153-160. (doi:10.1161/CIRCHEARTFAILURE.108.766402)

Pratley RE, Nauck M, Bailey T, Montanya E, Cuddihy R, Filetti S, Thomsen AB, Sondergaard RE, Davies M \& Group L-D-S 2010 Liraglutide versus sitagliptin for patients with type 2 diabetes who did not have adequate glycaemic control with metformin: a 26-week, randomised, parallelgroup, open-label trial. Lancet 375 1447-1456. (doi:10.1016/S01406736(10)60307-8)

Ray KK, Seshasai SR, Wijesuriya S, Sivakumaran R, Nethercott S, Preiss D, Erqou S \& Sattar N 2009 Effect of intensive control of glucose on cardiovascular outcomes and death in patients with diabetes mellitus: a meta-analysis of randomised controlled trials. Lancet 373 1765-1772. (doi:10.1016/S0140-6736(09)60697-8)

Read PA, Khan FZ, Heck PM, Hoole SP \& Dutka DP 2010 DPP-4 inhibition by sitagliptin improves the myocardial response to dobutamine stress and mitigates stunning in a pilot study of patients with coronary artery disease. Circulation. Cardiovascular Imaging 3 195-201. (doi:10.1161/ CIRCIMAGING.109.899377)

Read PA, Hoole SP, White PA, Khan FZ, O'Sullivan M, West NE \& Dutka DP 2011 A pilot study to assess whether glucagon-like peptide-1 protects the heart from ischemic dysfunction and attenuates stunning after coronary balloon occlusion in humans. Circulation. Cardiovascular Interventions 4 266-272. (doi:10.1161/CIRCINTERVENTIONS.110. 960476)

Robinson LE, Holt TA, Rees K, Randeva HS \& O'Hare JP 2013 Effects of exenatide and liraglutide on heart rate, blood pressure and body weight: systematic review and meta-analysis. BMJ Open 3 e001986. (doi:10.1136/bmjopen-2012-001986)

Russell-Jones D, Cuddihy RM, Hanefeld M, Kumar A, Gonzalez JG, Chan M, Wolka AM, Boardman MK \& Group D-S 2012 Efficacy and safety of exenatide once weekly versus metformin, pioglitazone, and sitagliptin used as monotherapy in drug-naive patients with type 2 diabetes (DURATION-4): a 26-week double-blind study. Diabetes Care 35 252-258. (doi:10.2337/dc11-1107)

Scirica BM, Bhatt DL, Braunwald E, Steg PG, Davidson J, Hirshberg B, Ohman P, Price DL, Chen R, Udell J et al. 2011 The design and rationale of the saxagliptin assessment of vascular outcomes recorded in patients with diabetes mellitus-thrombolysis in myocardial infarction (SAVOR-TIMI) 53 study. American Heart Journal 162 818-825.e6. (doi:10.1016/j.ahj.2011.08.006) 
Shibata R, Sato K, Pimentel DR, Takemura Y, Kihara S, Ohashi K, Funahashi T, Ouchi N \& Walsh K 2005 Adiponectin protects against myocardial ischemia-reperfusion injury through AMPK- and COX-2-dependent mechanisms. Nature Medicine 11 1096-1103. (doi:10.1038/nm1295)

Sivertsen J, Rosenmeier J, Holst JJ \& Vilsboll T 2012 The effect of glucagon-like peptide 1 on cardiovascular risk. Nature Reviews. Cardiology 9 209-222. (doi:10.1038/nrcardio.2011.211)

Sokos GG, Nikolaidis LA, Mankad S, Elahi D \& Shannon RP 2006 Glucagonlike peptide-1 infusion improves left ventricular ejection fraction and functional status in patients with chronic heart failure. Journal of Cardiac Failure 12 694-699. (doi:10.1016/j.cardfail.2006.08.211)

Sun F, Yu K, Wu S, Zhang Y, Yang Z, Shi L, Ji L \& Zhan S 2012 Cardiovascular safety and glycemic control of glucagon-like peptide-1 receptor agonists for type 2 diabetes mellitus: a pairwise and network meta-analysis. Diabetes Research and Clinical Practice 98 386-395. (doi:10.1016/j.diabres.2012.09.004)

Thrainsdottir I, Malmberg K, Olsson A, Gutniak M \& Ryden L 2004 Initial experience with GLP-1 treatment on metabolic control and myocardial function in patients with type 2 diabetes mellitus and heart failure. Diabetes \& Vascular Disease Research 140-43. (doi:10.3132/dvdr.2004.005)

Timmers L, Henriques JP, de Kleijn DP, Devries JH, Kemperman H, Steendijk P, Verlaan CW, Kerver M, Piek JJ, Doevendans PA et al. 2009 Exenatide reduces infarct size and improves cardiac function in a porcine model of ischemia and reperfusion injury. Journal of the American College of Cardiology 53 501-510. (doi:10.1016/j.jacc. 2008.10.033)

Tomas E, Wood JA, Stanojevic V \& Habener JF 2011 GLP-1-derived nonapeptide GLP-1(28-36)amide inhibits weight gain and attenuates diabetes and hepatic steatosis in diet-induced obese mice. Regulatory Peptides 169 43-48. (doi:10.1016/j.regpep.2011.04.006)

Tzoulaki I, Molokhia M, Curcin V, Little MP, Millett CJ, Ng A, Hughes RI, Khunti K, Wilkins MR, Majeed A et al. 2009 Risk of cardiovascular disease and all cause mortality among patients with type 2 diabetes prescribed oral antidiabetes drugs: retrospective cohort study using UK general practice research database. BMJ 339 b4731. (doi:10.1136/ bmi.b4731)

Ussher JR \& Drucker DJ 2012 Cardiovascular biology of the incretin system. Endocrine Reviews 33 187-215. (doi:10.1210/er.2011-1052)
Varanasi A, Patel P, Makdissi A, Dhindsa S, Chaudhuri A \& Dandona P 2012 Clinical use of liraglutide in type 2 diabetes and its effects on cardiovascular risk factors. Endocrine Practice 18 140-145. (doi:10.4158/ EP11169.OR)

Vilsboll T 2007 Liraglutide: a once-daily GLP-1 analogue for the treatment of type 2 diabetes mellitus. Expert Opinion on Investigational Drugs 16 231-237. (doi:10.1517/13543784.16.2.231)

White WB, Bakris GL, Bergenstal RM, Cannon CP, Cushman WC, Fleck P, Heller S, Mehta C, Nissen SE, Perez A et al. 2011 EXamination of cArdiovascular outcoMes with alogliptIN versus standard of carE in patients with type 2 diabetes mellitus and acute coronary syndrome (EXAMINE): a cardiovascular safety study of the dipeptidyl peptidase 4 inhibitor alogliptin in patients with type 2 diabetes with acute coronary syndrome. American Heart Journal 162 620-626.e1. (doi:10.1016/j.ahj. 2011.08.004)

Xiao YF, Nikolskaya A, Jaye DA \& Sigg DC 2011 Glucagon-like peptide-1 enhances cardiac L-type $\mathrm{Ca}^{2+}$ currents via activation of the cAMPdependent protein kinase A pathway. Cardiovascular Diabetology 106. (doi:10.1186/1475-2840-10-6)

Ye Y, Keyes KT, Zhang C, Perez-Polo JR, Lin Y \& Birnbaum Y 2010 The myocardial infarct size-limiting effect of sitagliptin is PKA-dependent, whereas the protective effect of pioglitazone is partially dependent on PKA. American Journal of Physiology. Heart and Circulatory Physiology 298 H1454-H1465. (doi:10.1152/ajpheart.00867.2009)

Yin M, Sillje HH, Meissner M, van Gilst WH \& de Boer RA 2011 Early and late effects of the DPP- 4 inhibitor vildagliptin in a rat model of post-myocardial infarction heart failure. Cardiovascular Diabetology 10 85. (doi:10.1186/1475-2840-10-85)

Zaruba MM, Theiss HD, Vallaster M, Mehl U, Brunner S, David R, Fischer R, Krieg L, Hirsch E, Huber B et al. 2009 Synergy between CD26/DPP-IV inhibition and G-CSF improves cardiac function after acute myocardial infarction. Cell Stem Cell 4 313-323. (doi:10.1016/j.stem.2009.02.013)

Zhao T, Parikh P, Bhashyam S, Bolukoglu H, Poornima I, Shen YT \& Shannon RP 2006 Direct effects of glucagon-like peptide-1 on myocardial contractility and glucose uptake in normal and postischemic isolated rat hearts. Journal of Pharmacology and Experimental Therapeutics 317 1106-1113. (doi:10.1124/jpet.106.100982)

Received in final form 15 July 2013

Accepted 5 August 2013

Accepted Preprint published online 7 August 2013
C 2014 Society for Endocrinology Printed in Great Britain
Published by Bioscientifica Ltd 